\title{
Towards a Dynamic Resource-Based View: Insights from Austrian capital and Entrepreneurship Theory
}

\author{
Foss, Nicolai Juul; Ishikawa, Ibuki
}

Document Version

Final published version

Publication date:

2006

License

CC BY-NC-ND

Citation for published version (APA):

Foss, N. J., \& Ishikawa, I. (2006). Towards a Dynamic Resource-Based View: Insights from Austrian capital and Entrepreneurship Theory. Center for Strategic Management and Globalization. SMG Working Paper No. 6/2006

Link to publication in CBS Research Portal

\footnotetext{
General rights

Copyright and moral rights for the publications made accessible in the public portal are retained by the authors and/or other copyright owners and it is a condition of accessing publications that users recognise and abide by the legal requirements associated with these rights.

Take down policy

If you believe that this document breaches copyright please contact us (research.lib@cbs.dk) providing details, and we will remove access to the work immediately and investigate your claim.
}

Download date: 26. Apr. 2023 


\title{
Towards a Dynamic Resource- Based View: Insights from Austrian capital and Entrepreneurship Theory
}

\author{
Nicolai J. Foss \\ Ibuki Ishikawa \\ SMG WP 6/2006
}

April 2006 
SMG Working Paper No. 6/2006

April 2006

ISBN: 87-91815-22-3

Center for Strategic Management and Globalization Copenhagen Business School

Porcelænshaven 24

2000 Frederiksberg

Denmark

www.cbs.dk/smg 


\title{
TOWARDS A DYNAMIC RESOURCE-BASED VIEW: INSIGHTS FROM AUSTRIAN CAPITAL AND ENTREPRENEURSHIP THEORY
}

\author{
Nicolai J. Foss \\ Center for Strategic Management and Globalization \\ Copenhagen Business School \\ Porcelænshaven 24, $2^{\text {nd }}$ fl.; 2000 Frederiksberg; Denmark \\ njf.smg@cbs.dk \\ and \\ Department of Strategy and Management \\ Norwegian School of Economics and Business Administration \\ Breiviksveien 40; N-5045; Bergen; Norway

\section{Ibuki Ishikawa} \\ Visiting Scholar, Center for Strategic Management and Globalization \\ Copenhagen Business School \\ Porcelænshaven 24, $2^{\text {nd }}$ fl.; 2000 Frederiksberg; Denmark \\ ii.smg@cbs.dk \\ and \\ Department of Business Administration \\ Ritsumeikan University. \\ 1-1-1 Nojihigashi, Kusatsu, Shiga, Japan, 525-8577 \\ ba084989@ba.ritsumei.ac.jp
}

\section{April 2006}

Keywords: Resource-based view, Austrian capital theory, complexity theory, entrepreneurs, competitive advantage.

JEL Code: B53, D21, L23, M1 


\title{
TOWARDS A DYNAMIC RESOURCE-BASED THEORY: INSIGHT FROM AUSTRIAN CAPITAL AND ENTREPRENEURSHIP THEORY
}

\begin{abstract}
The dominant view in the strategic management field is the resource-based view ("RBV"). It has often been observed that the RBV is lacking in the dynamic dimension. For example, processes of building competitive advantages by means of combining existing complementary resources in novel ways are not inquired into. We argue that the RBV may profitably draw on Austrian (Misesian) and Knightian insights in entrepreneurship and capital theory, particularly in its Lachmannian manifestation, in order to strengthen its dynamic components. We link the RBV and Austrian ideas in the context of the theory of complex systems pioneered by Herbert Simon. We draw a number of implications for strategic management from this synthesis, notably into resource value and sustainability of competitive advantage.
\end{abstract}




\section{INTRODUCTION}

As a field of inquiry, strategic management is heavily indebted to economics (Kay, 1990). Thus, the first serious analytical work in the field, namely, Michael Porter’s $(1980,1985)$ work, was essentially an application of the industrial organization economics of Bain (1956) and Scherer (1980) (cf. Porter, 1981). Later currents in industrial organization, such as contestable markets theory (Baumol, Panzar and Willig, 1982), game theoretical new industrial organization (Tirole, 1989), and the Chicago-UCLA approach (Demsetz, 1973) have also had enormous influence on strategic management. More specifically, contestable markets theory and new industrial organization have dominated the commitment approach (Ghemawat, 1991), and the Chicago-UCLA approach to industrial organization has motivated the resource-based view (Lippman and Rumelt, 1982; Rumelt, 1984; Barney, 1986, 1991; Peteraf, 1993; Foss, 2000). While Austrian economics has also had some influence, it has been a rather minor and largely indirect one (e.g., Jacobsson, 1992), and, in this paper, we will attempt to excert some additional influence. We argue that strategic management's now dominant perspective, the resource-based view (the "RBV”), stands to benefit by drawing explicitly on Austrian economics, resulting in a "dynamic resource-based view.”

The strengths and weaknesses of the underlying approaches to economics are reflected in the strategic stances they inspire. Notably, the RBV emerged very much as a critical response to the black box view of the firm defended by Porter (1980) as part of his positioning approach, which he had adopted from the industrial organization paradigm (Bain, 1956; Scherer, 1980). Inspired by traditional SCP work, Porter focused on product market "imperfections" (i.e., entry and mobility barriers) as the sources of firm profitability; the RBV, by contrast, directed attention to informational asymmetries in factor markets and on firm-specific resources as the "imperfections" that underlie differential rents. The underlying model accordingly shifted from oligopoly or monopoly to competive equilibrium. That is, there was a shift away from models where firm-level competitive advantages are synonymous with exploiting consumers through imposing welfare deadweight losses (Porter, 1980, 1981) to those where competitive advantages were reflected in the earning of efficiency rents (Lippman and Rumelt, 1982). 
From an Austrian perspective, there is surely much to applaud in the RBV. The emphasis on the control of unique resources as the only source of long-lasting advantage (cf. Kirzner, 1973) and the efficency view of competitive activities offer laudable contributions to strategy research. Also, the stress on firm and resource heterogeneity suggests linkages to Austrian capital theory, and the emphasis on differential expectations and asymmetric information (e.g., Barney, 1986) suggests linkages to Austrian subjectivism (Lachmann, 1977, 1986).

However, a number of distinctive features of the RBV set it apart from Austrian economics. Thus, Foss (2000, 2003) argued that the resource-based view has a number of limitations because of its heavy, if implicit, reliance on the competitive equilibrium model. In essence, the RBV is concerned with the rent-generating ability of resources in equilibrium (Lippman and Rumelt, 1982) and resources are therefore supposed to be always put to their best uses. The issue of how resources and resource applications are discovered (the entrepreneurial process) is bypassed in this approach and the theoretical core of the approach is fundamentally static in nature (Barney, 2001; Lewin and Phelan, 1999). Thus, from an Austrian perspective, the RBV is a halfway house. While it does have a number of desirable features, it seeks to capture these crucial ingredients of the competitive, entrepreneurial market process (Hayek 1948; Mises 1949; Lachmann 1986) in an equilibrium framework rather than a process framework. ${ }^{1}$ Heterogeneous resources, differential expectations, etc. are taken as data for the analysis. This is, of course, in contrast to the genetic-causal approach that is a hallmark of the Austrian approach (Cowan and Rizzo, 1996; Salerno, 1999).

The purpose of this paper is to go beyond noting shortcomings in the RBV and suggest how such shortcomings may be remedied by drawing more on process notions. After discussing the RBV in an Austrian perspective, therefore, we offer a way of understanding how firms may build competitive advantage by acquiring and accessing heterogeneous resources, rather than specifying what are essentially equilibrium conditions, namely the conditions for sustained competitive advantage (as in

\footnotetext{
${ }^{1}$ Partial exceptions are Jacobson (1992), Westgren (1995), Hill and Deeds (1996), Roberts and Eisenhardt (2003), and, from an Austrian perspective, Lewin and Phelan (1999, 2000, 2002, Lewin 2005). For a general statement, inspired by Austrian economics, of the importance of process in the context of management, see Chiles (2003).
} 
Barney, 1991; Peteraf, 1993).

The paper is structured as follows. First, we briefly present and discuss the theoretical framework of $\mathrm{RBV}$ in order to identify the limitations of the RBV that stems from its reliance on the equilibrium framework. Second, we reinterpret the central notion of resources from an Austrian perspective, focusing on capital theory and entrepreneurship theory in particular. Finally, we discuss some possible future research avenues toward a dynamic resource based view. In sum, we extend the RBV in an Austrian capital-theoretic setting where the exercise of judgment relating to combining heterogeneous but complementary capital assets is a key business problem. We are not the first to discuss the RBV from an explicitly Austrian perspective (see especially Lewin and Phelan, 1999, 2000, 2002) or even from an Austrian capital theory perspective (Lewin, 2005). However, the present work differs by giving more attention to the RBV and taking a more critical view of the equilibrium framework (see also Matthews 2006 on this). Also, we relate the discussion to the theory of complex systems (Simon, 1962; Kauffman, 1993) and draw some novel implications of relevance to the RBV.

\section{THE RESOURCE-BASED VIEW: AN EQUILIBRIUM APPROACH}

The dominant approach in contemporary strategic management is the RBV, first established in the mid-1980s by Wernerfelt (1984), Rumelt (1984) and Barney (1986), and further developed by these and other writers. Economic equilibrium, particularly in the form of competitive equilibrium, is central in this approach (Foss, 2000), not only as a yardstick for welfare analysis (as in neoclassical economics) but also — in a modified version — as the foundational model. Indeed, the dominance of the RBV has meant that the key issue of strategic management is usually defined as the problem of achieving sustained competitive advantage in the sense of earning (efficiency) rents in equilibrium. This is a special case of a broader view that "[t]he field of strategy is concerned with the conditions under which the microeconomic equilibrium of homogenous firms with zero profits can be overcome” (Knott, 1998: 3).

\section{The Chicago Approach as a Foundation for the RBV}

Although the RBV is often associated with the work of Edith Penrose (1959) (e.g., Kor and Mahoney 
2000), at least in its more explicitly economics-oriented incarnations (such as Lippman and Rumelt, 1982; Barney, 1986, 1991; Peteraf, 1993), it owes much more to the Chicago approach to industrial organization (Brozen, 1971; Demsetz, 1973, 1974, 1982 1989; Peltzman, 1977). ${ }^{2,3}$ Briefly, a central aim of this approach is to explain long-lived performance differences in terms of efficiency rents existing under competitive conditions rather than in terms of monopolistic abuse of market power. The Chicago industrial organization approach was explicitly developed through the 1970s in open opposition to the Harvard industrial organization approach that was dominant in the 1960s and was the main source of inspiration for Porter's early work (Porter, 1980). ${ }^{4}$ To resource-based writers, and notably the highly influential Richard Rumelt and Jay Barney, the Chicago approach represented an appealing way to reconcile the emphasis on idiosyncratic and firm specific factors that is characteristic of the strategic management field with economic equilibrium theory (Foss 2000).

The Chicago legacy is directly present in an often cited paper by Peteraf (1993), which explicitly casts the RBV in terms of rents in competitive equilibrium, using the basic demand and supply apparatus of economics textbooks to graphically illustrate this. It is perhaps less visible in the even more influential Barney (1991) paper, but it is still there. Consider Barney’s (1991) statement of the RBV. He (1991: 102) explains that

A firm is said to have a competitive advantage when it is implementing a value creating strategy not simultaneously being implemented by any current or potential competitors. A firm is said to have a sustained competitive advantage when it is implementing a value creating strategy not simultaneously being implemented by any current or potential competitors and when these other firms are unable to duplicate the benefits of

\footnotetext{
${ }^{2}$ Aka the "Chicago-UCLA approach.” Both Rumelt and Bamey were part of the UCLA environment.

${ }^{3}$ However, this is not true of those parts of the RBV that are taken up with the analysis of diversification (e.g., Wemerfelt, 1984; Montgomery and Wernerfelt, 1988), where the Penrosian influence is more direct.

${ }^{4}$ Although we here argue that that relying on the equilibrium-oriented Chicago-UCLA approach has limited the theoretical development of RBV, we acknowledge, of course, that with respect to implications drawn for antitrust policy, there is substantial convergence between the Austrians and Chicago-UCLA economists.
} 
this strategy.

Thus, sustained competitive advantage is defined in terms of situations in which all attempts by competitor firms at imitating or substituting a successful firm have ceased, that is, equilibrium obtains. Barney's analysis of the conditions under which such situations obtain is entirely in line with the Chicago school in its emphasis on resources (i.e., input factors) being costly to copy, etc. (compare Brozen, 1971; Demsetz, 1973, 1974, 1982, 1989; Peltzman, 1977). ${ }^{5}$ His argument that all performance differences are explainable in terms of differential efficiencies of the resources that underlie the strategies, and that, therefore, superior returns are fully compatible with social welfare, is straight out of the Chicago book (e.g., Demsetz 1974, 1989). Barney’s (1986) earlier emphasis on factor market rather than product market imperfections as a condition of competitive advantage is also vintage Chicago (e.g., Demsetz, 1973).

Although borrowing from the Chicago approach in some ways furthered strategic management, the set of phenomena relevant to strategic management that can be framed by relying on this approach is rather limited. This follows from the basic Chicago research methodology, which casts virtually any social phenomenon in terms of competitive equilibrium — what Chicago School insider Melvin Reder (1982) characterized as the "tight prior equilibrium" assumption. The core of this approach is that "in the absence of sufficient evidence to the contrary, one may treat observed prices and quantities as good approximations to their long-run competitive equilibrium values” (Reder, 1982: 12). The resulting notion of competitive equilibrium may not entirely be of the perfect competition textbook variety; a superior technology, for example, may be costly to imitate (Demsetz, 1973; Lippman and Rumelt, 1982) or there may be some asymmetric information in factor markets (Demsetz, 1973; Barney, 1986). Still, the basic RBV model is founded on a patched-up competitive equilibrium model (Foss, 2003).

\footnotetext{
${ }^{5}$ More specifically, in order to hold a "potential” of sustained competitive advantage, a resource “... must have four attributes: (a) it must be valuable ... (b) it must be rare among a firm's current and potential competition, (c) it must be imperfectly imitable, and (d) there cannot be strategically equivalent substitutes for this resource that are valuable but neither rare or imperfectly imitable” (Barney, 1991: 105-6). Given these criteria, sustained competitive advantage obtains when a firm implements a unique strategy that is implemented by means of resources that conform to the four criteria above.
} 


\section{Some Shortcomings Caused by the Equilibrium Orientation of the RBV}

Austrian economists have consistently criticized the role that the competitive equilibrium model continues to play in mainstream economics, where it serves as the core model and the ultimate normative yardstick (the most systematic statement may well be Machovec, 1995). Here we discuss some of the unfortunate consequences of grounding research in strategic management on such a model.

Disequilibrium is not considered. Since, by the basic Chicago methodology, all phenomena that relate to strategic management must be expressed in terms of equilibrium, those aspects of strategic management that are best understood as disequilibrium phenomena drop out of sight. Notably, it is hard to make room for entrepreneurship in an "equilibrium-always" approach because the essence of entrepreneurship is to either restore or upset equilibrium (Kirzner, 1973; Machovec, 1995; Lewin and Phelan, 2002). Of course, it is possible to use equilibrium models to examine the effects of entrepreneurship (e.g., in terms of earning rents in equilibrium), but the models themselves do not allow us to understand the phenomenon itself, except in the very stylized form of draws from probability distributions over technologies with differing costs (as in Lippman and Rumelt, 1982). Related to this, understanding dynamics becomes at best a matter of carrying out comparative-static exercises, that is, comparing equilibria where the variables differ because of changes in underlying data. ${ }^{6}$ While disequilibrium characterizes the transition from one equilibrium to another, it is not treated in the model. One implication is that the disequilibrium process of combining resources in novel ways (i.e., building new competitive advantages) is not inquired into.

Resource attributes are "objectively" given. As shown earlier, RBV scholars argue that resources need to meet certain necessary conditions — such as those in the Barney (1991) or the Peteraf (1993) frameworks — to yield a sustained competitive advantage. The analyst, whether businessman,

6 Foss (1996b) speculates that the suppression of disequilibrium issues is what explains the branching of the "resource-based view," broadly conceived, into, first, the RBV proper, and, second, various “competence-based," "capabilities," "dynamic capabilities," etc. approaches which all try to highlight dynamics in various ways (e.g., Hamel and Prahalad, 1994). Priem and Butler (2001a) recently also noted the lack of dynamics in the RBV. 
consultant or academic, analyzes firm resources in these terms, ending up, perhaps, with a shortlist of resources that are strategically important in the sense that they meet the necessary conditions of SCA. Analysts may not reach the same conclusion, but this is because some analysts may not have information about resource characteristics that other analysts do possess. In particular, analysts on the supply side of factor markets may not possess the same information as a firm on the demand side with respect to the discounted net present value of a resource when applied in the operations of the firm. This means that the firm may be able to purchase the resource at a price below the DNPV (Barney 1986; Makadok and Barney 2001). However, if this information were revealed to the supply side of the market, factor prices would immediately appreciate.

From an Austrian perspective, this approach tends to negate the subjectivity of knowledge and of individual plans (Hayek, 1945; Lachmann, 1977, 1986; Kirzner 1997; Salerno 1999). As Vaughn (1994) argues,one of the key uniting characteristics of Austrians of otherwise different stripes is their emphasis on the subjectivity of knowledge and expectations. In an Austrian perspective, the future contribution of resources to value creation and competitive advantages is not "information", but an entrepreneurial appraisal (Menger 1871; Mises 1949; Salerno 1999), which is based on the entrepreneur's prior knowledge (Shane 2000) and the mental framework he applies to the process of appraisal (Penrose 1959; Lacmann 1986). As Foss, Foss, Klein, and Klein (2005) argue, resource attributes such as characteristics, function, and possible uses are not objectively given, "inherent" characteristics of resources, but are first constructed as part of entrepreneurial appraisal activities and may then become actualized when entrepreneurial plans are implemented. As Lachmann (1956: 2) observes in a related context, blast furnaces and beer barrels are not capital goods because of their physical properties, but because of the role they play in entrepreneurial plans. This fundamental subjectivist insight, however, is not adequately captured in the RBV.

Narrow conceptualization of competitive activities. Hayek (1946) was probably the first among many Austrians to note and criticize the narrow treatment of competitive activities that is implied in the competitive equilibrium model: “Advertising, undercutting, and improving (“differentiating”) the goods or services produced are all excluded by definition - 'perfect' competition means indeed the 
absence of all competitive activities” (1946: 96). In the RBV, competitive activities are primarily represented through those barriers at imitation that may protect the relevant rent stream in equilibrium, value capture being represented in terms of imitative competition. Thus, the set of competitive activities that is considered within the RBV is limited. While competition in terms of process innovations may be consistent with competitive equilibrium (Lippman and Rumelt, 1982), competition in terms of product differentiation, price discrimination, product innovation, etc. is not (Makowski and Ostroy, 2001).

Summing up. The real world phenomena that can be conceptualized and explained are to a large extent constrained by the underlying theories and models that the analyst applies. Many phenomena that would indeed seem to be central to strategic management cannot easily, if at all, be represented by means of a patched-up competitive equilibrium model. Industrial organization scholars normally concur with this basic methodological point because the competitive equilibrium model excludes the market phenomena they wish to focus on by its fundamental assumptions. But the point was here developed from an Austrian perspective: competitive equilibrium and its attendant assumptions of objectively given data do away with the competitive market process and the processes of entrepreneurial appraisal and action that constitute such an important part of this process. In the following section, we argue that it is possible to take a broader view of how to address the key issues of strategic management, while still keeping the fundamental thrust of the RBV. In particular, we argue that Austrian theories of capital and entrepreneurship are helpful for remedying the shortcomings of RBV discussed above.

\section{CAPITALAND ENTREPRENEURSHIP}

The RBV focuses on resources as analytical units for understanding firm-level sustained competitive advantage. We have no problem with ascribing a significant role to resources in the understanding of value creation and competitive advantage. We take issue, however, with the pure equilibrium orientation of the RBV, as this suppresses the role that entrepreneurship plays in appraising resources and deploying them to new uses, treats all knowledge about resource characteristics as objectified information rather than subjective constructs in the entrepreneurial imagination, and neglects the 
creation of new (strategic) resources through, for example, the combination and recombination of existing resources (Schumpeter, 1912; Lachmann, 1956; Nelson and Winter, 1982). In order to make the RBV capable of developing in these more dynamic directions we submit that it needs to be integrated with key Austrian insights in entrepreneurship and capital theory. Much of this section will therefore be devoted to discussing these insights and show why they matter to the RBV.

\section{The Importance of Capital Theory}

Mainstream economics often approaches productive activities on the basis of a highly stylized model that provides only a 'snapshot' view of them (Nelson and Winter, 1982). The firm is treated as a production function, a black box that transforms inputs (land, labor, capital) into output (consumer goods) instantaneously. As is widely recognized, this model omits the "institutional structure of production” (Coase, 1992), rarely looking inside the black box to see how input factors are actually combined, and therefore how hierarchies are structured, how incentives are provided, how teams are organized, and so on. The production function view also implies that productive processes themselves are pressed into an atemporal setting in which factor inputs are assumed to be always in their best uses, as captured by the production possibility frontier. (The RBV makes similar assumptions, as we have seen). This, in turn, implies that production is a one-stage process (at least for purposes of illustration), with only factors and final goods, rather than a complex, multi-stage process unfolding through time and employing rounds of intermediate goods (Young, 1928; Leijonhufvud, 1986; Garrison, 2001; Lewin, 1999). Sometimes capital is treated as a homogeneous factor of production, that is, the $\mathrm{K}$ that appears in the production function along with $\mathrm{L}$ for labor. In this perspective, capital goods are "like drops of water” in the sense of being perfect substitutes (Lachmann, 1947: 114), or what Robert Solow called “shmoo."

We note also that the kind of economics that was dominant in strategic management before the advent of the RBV, namely, industrial organization economics as filtered through Porter's (1980, 1981) approach, is based on the production function framework with its attendant assumptions about full knowledge of production possibilities and production factors that are (or can be taken to be) 
homogenous with factor classes. Seen in this light, the RBV represented a large step forward because it brought resource or capital heterogeneity onto center stage in the analysis of differential firm performance. With Solowian "shmoo capital”, any capital combination that could be implemented by firm x could — trivially, as capital goods were economically identicaŁ —also be implemented by firm y (see also Barney, 1991). Entrepreneurs would equalize returns from implementing capital/resources in production. Things are very different in a world where capital is fundamentally heterogeneous. In such a world resources may be combined in multiple ways; entrepreneurs may not have the wits to ascertain all possible combinations; only some combinations of heterogeneous resources are valued by the price system (prices may not exist for a new innovative product based on a new combination of resources); some resources are only valued if other resources are applied in production; some resources may be knowledge resources that are costly to measure, trade and protect; etc. In such a world, entrepreneurial judgment and action is necessary to appraise resource combinations and carry out the commercial ventures that correspond to the specific combinations of resources. This is the world of Austrian economics in general, and Austrian capital theory in particular. Although the RBV is not explicitly based on any capital theory, we submit that Austrian capital theory is a natural complement to the $\mathrm{RBV}^{7}$

\section{Austrian Capital Theory}

Contrary to neoclassical orthodoxy, Austrian economics places capital heterogeneity and the temporal dimension of capital goods at center stage, a move that has uniquely characterized the Austrian School since Carl Menger (1871) (Garrison, 2001; Lewin, 1999, 2005). Thus, Menger (1871) famously characterized goods in terms of "orders": goods of lowest order are those consumed directly, tools and machines used to produce those consumption goods are of a higher order, and those capital goods used to produce the tools and machines are of an even higher order. Building on his theory that the value of all goods is determined by their ability to satisfy consumer wants, Menger showed that the value of the higher-order goods is given (“imputed") by the value of the lower-order goods they serve to produce.

\footnotetext{
${ }^{7}$ Foss, Foss, Klein and Klein (2005) present a related argument. They show how the Coasian theory of the firm may be advanced by Austrian capital theory.
} 
Ludwig Lachmann (1947, 1956, 1976, 1986) was, along with Hayek (1941) and Kirzner (1966), among those Austrians that most directly picked up on the original Mengerian idea, eschewing all attempts to homogenize capital and insisting on the unique insights that follow from treating capital "as a collection of heterogeneous goods” (Vaughn, 1994). ${ }^{8}$ In the following we build on Lachmann's work. Inspired by Hayek (1941), Lachmann (1956) developed a fundamentally subjectivist conception of "capital structure", the two key concepts of which are capital heterogeneity and capital complementarity. "In the sphere of human action, Structure implies Function, and Function, where a number of factors is involved, implies co-ordination and complementarity" (p.114). Every specific piece of capital equipment is designed for a certain purpose, so that capital heterogeneity emerges from “[p]roducts of the human mind, artifacts, produced in accordance with a plan” (p.112). In a capital structure, each capital good has a definite function and the various goods are, too varying degrees, complements (see also Lachmann, 1986: Chapter 4). Indeed, it seems that in reality individual capital goods should be expected to be substitutable for some other use. For example, each locomotive is a complement to a number of wagons but is also, at the same time, to a greater or lesser extent, a substitute for any other locomotive (Lachmann, 1947: 109). However, if this is so, the next question, Lachmann points out, is to ask "whether complementarity or substitutability is the dominant relationship, or more precisely, under what conditions we expect one or the other to predominate” (p.109). Lachmann (1947: 110) continues:

Factor complementarity and substitutability are phenomena belonging to different provinces of the realm of action. Complementarity is a property of means employed for the same end, or a group of consistent ends. All the means jointly employed for the same end, or such ends, are necessarily complements. Factor complementarity

\footnotetext{
${ }^{8}$ One of the most critical points, among many, that distinguishes Austrian economists from mainstream economists is the Austrian economist's subjectivism. Austrian economists see capital structure as an essentially subjective phenomenon relating both to Mengerian time and Hayekian disequlibranting tendencies, and do so in attempt to develop an alternaitive economic paradigm to mainstream economics. We think this subjective perspective on capital goods (or resource in the sense of RBV) offers deep insights and makes a powerful contributions to the understanding of a strategic issues.
} 
presupposes a plan within the framework of which each factor has a function.

Thus, when we say that a certain capital good that is functionally connected with a preceding production plan may be substitutable for other forms of production or usage, we must presuppose an alternative plan for its usability. Toward this new end, the capital good must be a complement, not a substitute. In fact, Lachmann argues, substitutability is a "phenomenon of change” that arises whenever an initial plan has gone wrong (p.110). That is, substitutability becomes meaningful only after a factor can no longer be part of an existing plan. In this respect, complementarity is a feature of stability, implying a certain technical rigidity (Lewin, 2005: 14). The capital goods that lose their function in an initial plan have to be scrapped or, at best, regrouped within another plan (what Lachmann [1956:2] calls “multiple specificity”). ${ }^{9}$

Thus, it is clear that Lachmann's capital theoretic outlook is firmly embedded in a process view of economic activity. Consistent with this, Lachmann (1986: 65) took issue with the Marshallian notion that the "short run” may be defined as the capital stock being given: “. . . short-run change in the pattern of use of existing capital goods in the form of a reshuffling of capital combinations is ubiquitous.” Contrast this with the RBV core model, which is essentially a model of firms with given endowments of resources, earning differential rents on these in equilibrium, an equilibrium which is defined by all attempts at imitating a successful firm's strategy having ceased (so that no "reshuffling of capital combinations" goes on). Such an equilibrium has no place in the Lachmannian scheme.

Lachmann further points out that many productive activities are not automatically coordinated by an anonymous price system and that the role of specifying, modifying, and making decisions on the concrete form that the capital resource is potentially to have is the significant function of the entrepreneur (1976: 16). ${ }^{10}$ Therefore, the form of capital as structure is derived from entrepreneurial

\footnotetext{
${ }^{9}$ One implication is that the view that capital complementarity and substitutability are alternative modes of the relationship between capital goods in the same situation rests on a fallacy (Lachmann 1947: 110).

${ }^{10}$ Lachmann distinguishes the role of the entrepreneur from the function of the manager. He says the revision of plans is the function of the entrepreneur and the carrying out of existing plans is the function of the manager (See the footnote.1, p.113). In our discussion, we follow his distinction although the definition of entrepreneurship may be otherwise in practice (Gartner, 1990).
} 
plans. As entrepreneurial action is a crucial antecedent to heterogeneous capital/resources, it would seem that the entrepreneur must have a distinct role in a dynamic RBV.

\section{Entrepreneurship and Heterogeneous Capital}

If capital were a single "good” with one price, we would only have to choose between capital-intensive and labor-intensive production methods (or among types of labor). Few “calculation problems” (Mises, 1949) would exist in such a world. Moreover, as Foss et al. (2006) argue, in a world of homogenous capital goods (resources), decision problems would be trivialized as all capital goods possess the same attributes, and thus the costs of inspecting, measuring, and monitoring the attributes of productive assets would be trivial (Barzel, 1997). Finally, a world of homogenous capital is a non-complex world, one in which decision-makers do not reach the bounds of their rationality (Simon, 1955).

The entrepreneur's primary function is to choose among the various combinations of inputs that are suitable for producing particular goods (and to decide whether these goods should be produced at all) based on current prices for the factors and expected future prices of the final goods. As Knight (1921) made clear, this requires judgment. This view traces its origins to the first systematic treatment of entrepreneurship in economics, namely Cantillon (1755). It conceives entrepreneurship as judgmental decision-making under conditions of uncertainty. Judgment refers primarily to business decision-making when the range of possible future outcomes, let alone the likelihood of individual outcomes, is generally unknown (what Knight terms uncertainty, rather than mere probabilistic risk). More generally, judgment is required "when no obviously correct model or decision rule is available or when relevant data is unreliable or incomplete" (Casson, 1993).

Judgment, then, is distinct from imagination or creativity (Lumpkin and Dess, 1996), innovation (Schumpeter, 1911), alertness (Kirzner, 1973), leadership (Witt, 1998), and other concepts of entrepreneurship that appear in the economics and management literatures. Judgment must be exercised in mundane circumstances, as Knight (1921) emphasized, for ongoing operations as well as new ventures. Kirznerian alertness is the ability to react to existing opportunities while judgment refers 
to the creation of new opportunities. ${ }^{11}$ Those who specialize in judgmental decision-making may be dynamic, charismatic leaders, but they need not possess these traits. In short, decision making under uncertainty is entrepreneurial, whether it involves imagination, creativity, leadership, and related factors or not.

Knight (1921) introduces judgment to link profit and the firm to uncertainty. Judgment primarily refers to the process of businessmen forming estimates of future events in situations in which the relevant probability distributions are themselves unknown. Entrepreneurship represents judgment that cannot be assessed in terms of its marginal product and which cannot, accordingly, be paid a wage (Knight 1921: 311). In other words, there is no market for the judgment that entrepreneurs rely on, and therefore exercising judgment requires the person with judgment to start a firm. Of course, judgmental decision makers can hire consultants, forecasters, technical experts, and so on. However, as we explain below, in doing so they are exercising their own entrepreneurial judgment. Judgment thus implies asset ownership, for judgmental decision-making is ultimately decision-making about the employment of resources. An entrepreneur without capital goods is, in Knight's sense, no entrepreneur. ${ }^{12}$

Lachmann (1956) and Kirzner (1966) added an important refinement to the Austrian theory of capital by explicitly linking it to the theory of capital. Earlier Austrian writers, particularly Böhm-Bawerk, tried to characterize the economy's capital structure in terms of its physical attributes. Böhm-Bawerk attempted to describe the temporal "length" of the structure of production by a single number, the “average period of production.” Kirzner's approach avoids these difficulties by defining capital assets in terms of subjective, individual production plans, plans that are formulated and continually revised by profit-seeking entrepreneurs. Capital goods should thus be characterized, not by their physical properties, but by their place in the structure of production as conceived by entrepreneurs. The actual

\footnotetext{
${ }^{11}$ In Kirzner's treatment, entrepreneurship is characterized as "a responding agency. I view the entrepreneur not as a source of innovative ideas ex nihilo, but as being alert to the opportunities that exist already and are waiting to be noticed” (Kirzner, 1973, p. 74).

${ }^{12}$ This contrasts with Schumpeter's and Kirzner's conceptions of entrepreneurship, in which entrepreneurship can be exercised without the possession of any capital goods.
} 
place of any capital good in the time sequence of production is given by the market for capital goods, in which entrepreneurs bid for factors of production in anticipation of future consumer demands. In the following, we show how these Austrian ideas may enrich the RBV.

\section{TOWARD A DYNAMIC RESOURCE-BASED VIEW}

As Peter Lewin (2005) rightly points out, one of the main contributions of post-Bohm Bawerkian Austrian capital theory is the emphasis on the structure dimensions of the capital stock rather than on the aggregate value dimension or notions such as roundaboutness. Indeed, echoing Lachmann, Lewin makes the case that the doctrinal history of economics demonstrates two very different approaches to capital theory, one structuralist (associated with Smith, Menger, the Hayek of the Pure Theory of Capital and Lachmann) and one quantitative (associated with Ricardo, Böhm-Bawerk and Solowian growth theory). In the latter approach, capital goods are not necessarily assumed to be homogenous, but there is a claim that they can be made commensurable in value terms, aggregated together, and that this aggregate result has economic significance. There is no particular emphasis on the relations between capital goods. In long-run equilibrium or full intertemporal equilibrium (á la Debreu 1959) the structuralist and the quantitative approaches become identical in their economic implications.

The RBV may be understood as being based on an implicit capital theoretical approach, one that stands with one leg in the structuralist camp (because of the emphasis on heterogeneous resources and relations of specificity and complementarity between these) and another leg in the quantitative camp (because of the equilibrium orientation of the RBV). Our argument in the following is essentially that the RBV will benefit from adopting a more structuralist, disequilibrium-oriented view of productive activities, and that taking this approach may enable the RBV to overcome the imitations implied by its present equilibrium focus and develop into a more dynamic view.

\section{Capital Structure, Complexity, and Productive Opportunities}

As Lewin (2005) observes, a structure of capital goods becomes a structure rather than just a list of heterogeneous capital goods because it is possible to say something about the overall structure from inspection of a few (possibly typical) capital goods and knowledge of principles of composition. This 
indicates that a capital structure may have systemic properties. We argue here that a natural complement to structural Austrian capital theory is the theory of complex systems associated with Simon (1962) and Kauffman (1993) (for various social science applications, see Levinthal, 1997; Fleming, 2001; Langlois, 2003; Nickerson and Zenger, 2004).

Simon (1962) defines “complexity” as obtaining when a large number of parts “interact in a nonsimple way” (1962: 468). Such complexity frequently takes the form of a hierarchy, that is, as a system that is composed of interrelated (complementary) subsystems. Each one of these subsystems are, in turn, hierarchical in nature, until some elementary subsystem is reached at the lowest level. "In hierarchic systems,” Simon explains, “... we can distinguish between the interactions among subsystems on the one hand, and the interactions within subsystems - i.e., among the parts of those subsystems - on the other” (1962: 473). This forms the basis for the often cited distinction between decomposable systems, in which the interactions among the subsystems are negligible; non-decomposable systems, in which the interactions among the subsystems are essential; and nearly decomposable systems, in which the interactions among the subsystems are weak, but not negligible (1962: 129). ${ }^{13}$

The relevance of these distinctions to Austrian capital theory is indicated by, for example, the reinterpretation of the Bohm-Bawerkian concept of roundabout'ness in such works as Hayek (1941) and Lachmann (1956) where increasing roundabout'ness is interpreted as an increasing number of capital goods with more complex interactions (typically an increasing number of relations of complementarity and specificity). Thus, increasing roundabout'ness implies that the overall capital structure becomes less “decomposable” in Simon’s terms.

Simon's (1962) main aim is to explain an important aspect of the ontology of the social and natural world. However, there is also an epistemological dimension to his discussion. Thus, he points out that an important aspect of what makes the social and natural world comprehensible is that they often involve phenomena that may be represented as nearly decomposable hierarchies; for example, "[s]ubparts belonging to different parts only interact in an aggregative fashion - the detail of their

\footnotetext{
${ }^{13}$ For an application to the theory of the firm with broadly Austrian features, see Langlois (2002).
} 
interaction can be ignored” (1962: 477). We can understand the system exactly because we can ignore these "details"; if we also had to comprehend the details it would be "beyond our capacities of memory and computation” (ibid.) to understand the full system. In other words, the epistemological problem of comprehending a complex system is eased when the system is decomposable or nearly decomposable (Schaefer, 1999).

One implication, which is often noted, is that problem-solving may proceed by means of decomposing problems into sub-problems (Loasby, 1976). Another implication is that systems, such as capital structures, that are close to the non-decomposable end of the spectrum may be hard to comprehend. In terms of later complexity research (e.g., Kauffman, 1993), the "landscape” of combinations of elements may have multiple peaks. More generally, a landscape is a mapping of how combinations of certain entities perform in terms of some metric. For example, theoretical biologists construct fitness landscapes that map gene combinations into fitness values. One may in an analogous manner think of a landscape of combinations of capital goods that are mapped into (appropriable) monetary values. Finding the optimal (highest) peak in such a landscape may be far from trivial. In general, work on search operations in complex systems (Levinthal, 1997; Fleming, 2001) demonstrates how the overall performance of the search effort is highly dependent on the characteristics of the system: whether they are decomposable, non-decomposable or nearly decomposable, for example. In particular, search operations in systems that lie close to the non-decomposable end of the spectrum are a tough undertaking, particularly when the search methods are primitive (e.g., gradient search), because in such systems the landscape of combinations of elements will have multiple peaks (in extreme cases, this may produce a "complexity catastrophe", Kauffman, 1993). ${ }^{14}$ This is consistent with the finding that firms often find it difficult to comprehend “architectural” knowledge, that is, knowledge of the multiple links between product components (Henderson and Clark, 1990). On the other hand, in strongly decomposed systems, the landscape may be single-peaked, so that even simple learning modes may quickly reach the peak.

\footnotetext{
${ }^{14}$ The height of peaks may here be taken as a measure of the profitability implications of a given combination of capital goods.
} 
Another related point is the notion that complex relations of complementarity between multiple resources/capital goods may be an important independent barrier to competitive imitation, even if all of the individual resources are perfectly imitable (Rivkin, 2000). A third implication is that there is a distinction between the interdependencies between elements/capital goods in a system/structure that are given to an omniscient observer and those interdependencies that can be seen or imagined by an agent such as a real-world entrepreneur.

\section{Search and Entrepreneurial Judgment}

The above ideas would be irrelevant in a full intertemporal equilibrium setting (Hayek, 1928; Debreu 1959). In such a world, all possible combinations of capital goods would be priced, and all prices would perfectly reflect scarcities. Imputation would be perfect. Under these circumstances, there would be no need for entrepreneurs who, based on their speculative appraisals, could test alternative combinations of capital goods in the market place (Mises, 1949; Salerno, 1999). As all prices would equal DNPVs (because of the combined assumptions of perfect foresight and competitive conditions), there would be no competitive advantages in this world. While all "strategies" in the sense of possibilities of action would be recognized and fully priced, any viable strategy would be as good (or bad) as any other (i.e., earning zero profits) (Denrell, Fang and Winter, 2003). There would be no need for any search in the landscape of combinations of capital goods, as the highest peaks would be immediately visible to entrepreneurs. This is what Lippman and Rumelt (2003: 1982) call “full strategic equilibrium” which maximizes surplus across the set of all possible assignments of all possible resources to all possible tasks. $^{15}$

However, with a very different social ontology, one characterized by dispersed knowledge (Hayek, 1948), genuine uncertainty (Knight, 1921; Mises, 1949), bounded rationality (Simon, 1955), and sheer ignorance (Kirzner, 1973), current prices cannot reflect all combinations of complementary capital goods, that is, all their “multiple specificities.” Instead, intertemporal resource allocation is taken care of

\footnotetext{
${ }^{15}$ They note in passing that " $[t$ the number of such combinations, in the real world, is literally noncomputable. The idea that firms actually operate at the maximum within this space is not credible” (ibid.).
} 
by entrepreneurs:

We are living in a world of unexpected change; hence capital combinations, and with them the capital structure, will be ever changing, will be dissolved and re-formed. In this activity we find the real function of the entrepreneur (Lachmann, 1956: 13).

How does entrepreneurial activity proceed? The best known treatments of entrepreneurship, those of Schumpeter (1934), Knight (1921) and Kirzner (1973), identify entrepreneurship with the commercialization of "new combinations," the exercise of judgment, and alertness, respectively. In these treatments there is, in actuality, rather little on the actual process of setting up the new means-ends framework (Choi, 1993; Harper, 1995). Entrepreneurial searching is somewhat played down. In fact, Kirzner appears to be at pains to dissociate himself from notions of search which he sees as wedded to to "Robbinsian maximization" (i.e., search implies an opportunity cost which can be economized). However, while serendipity, luck, and Kirznerian alertness surely play a role in entrepreneurial activity, so does active search (Casson, 1982; Shane, 2003). The theory of complex systems may add to the understanding of entrepreneurial search.

In terms of this perspective, we can think of the multiple possible combinations of capital goods as defining a landscape. If capital was Solowian shmoo, a homogenous fully substitutable substance, the landscape would be entirely flat as any combination of shmoo would be as good as any other combination. However, with capital heterogeneity, peaks emerge. As the capital structure becomes increasingly complex, the landscape becomes increasingly multi-peaked. Of course, with full information and perfect foresight, all entrepreneurs would enjoy a clear view of the "objectively" existing fitness landscape.. In actuality, however, entrepreneurs have only an imperfect model or theory (Choi, 1993; Harper, 1995) of the profitability implications of alternative combinations of capital goods. This is, of course, what is involved in notions of entrepreneurial appraisal and judgment.

As Lachmann (1956: 3) notes, “[t]he 'best' mode of complementarity is ... not a 'datum'. It is in no way 'given' to the entrepreneur who, on the contrary, as a rule has to spend a good deal of time and effort in finding out what it is.” Thus, the entrepreneur undertakes search. Search efforts may or may 
not give rise to the discovery of valuable capital combinations. In the literature on complex systems, search outcomes (such as valuable capital combinations) are usually said to depend on the mode of search (Levinthal, 1997) — for example, whether search takes place through incremental, trial-and-error search ("gradient search”) or whether it takes place based on explicit theories of cause-effect ("heuristic search”) — and, as already indicated, on the nature of the landscape over which search takes place. A potential Austrian critique of much of the complexity literature is that it often “dumbs down” human agents, for example, by portraying them as engaging in trial and error search with virtually no foresight. This is arguably quite true, but a broader conclusion from the literature is that, as a general rule, search modes should be matched to the characteristics of the landscape of combinations of knowledge elements in a discriminating manner. As indicated already, simple search modes will usually not suffice to discover the most valuable combinations of knowledge elements in multi-peaked landscapes. A "simple search mode" may be defined as one that makes no apriori assumptions about which knowledge elements are in the search space, how they may be connected, and the implications in terms of appropriable value. In this mode, search begins at an essentially arbitrary place and proceeds by means of trial and error. Search and learning becomes increasingly sophisticated as decision makers make explicit assumptions about which elements are relevant and how elements connect. It is arguably these latter kinds of search modes that are most closely allied to Austrian and Knightian notions of entrepreneurship, particularly because the Austrian and Knightian notions already assume substantial complexity in the form of a multiplicity of combinations of capital goods and uncertainty.

The search mode that entrepreneurs will apply and the judgments they will form are determined by their theories of the complexity of the problem they face (i.e., the architecture of the landscape of capital combinations) (Choi, 1993; Harper, 199X). This, in turn, is influenced by the entrepreneur's past experience. Shane (2000) argues and empirically demonstrates that entrepreneurial judgments are indeed influenced by experience because experience influences interpretation of the "facts." In a similar vein, Lachmann argues that experience is the "raw material of out of which all expectations are formed” (Lachmann, 1956:21). Since each expectation is formed as a result of a process in which a 
former expectation is revised through experience, the expectation that triggers entrepreneurial judgment might be different for each person implying that estimates of the DNPV of a capital good/resource differ widely across agents. In this situation, some agents may acquire a resource at a price below its DNPV. They may reap a rent from this resource by deploying the resource in production, or selling it. In contrast, if (a sufficient number of) agents hold the same estimate of the DNPV, price will equal DNPV and all rent will be absorbed in the price. By implication, expectational disequilibrium is a condition of competitive advantage, exemplifying the general importance that Lachmann ascribed to divergent expectations (Lachmann, 1977).

\section{Implications for Competitive Strategy}

There are a number of implications for the understanding of strategic management of the approach that we have sketched in the preceding pages. Some of these are discussed in the following.

Sustainability of competitive advantage. The key explanandum in RBV research is sustainability of competitive advantage, that is, the situation where a firm implements “... a value creating strategy not simultaneously being implemented by any current or potential competitors and when these other firms are unable to duplicate the benefits of this strategy” (Barney, 1991). While Austrians have no particular problem with the notion that firms may enjoy long-lived advantages from their control of unique capital goods (Kirzner, 1973), the equilibrium interpretation of sustained competitive advantage in the RBV is problematic: It implies a fixed, unchanging stock of resources, akin to a Marshallian short-run equilibrium (Lippman and Rumelt, 1982). In actuality, however, the resource/capital stock changes continuously as the entrepreneur adapts to changing circumstances (Lachmann, 1956; Lewin, 1999), and notions of equilibrium that presume that capital/resources remain unchanged do not jibe with an Austrian perspective. The implication is that sustainability should be removed from the fixed capital connotation, and redefined entirely in terms of the plans of firms and would-be imitators.

Pricing of resources. In a much cited paper, RBV scholars Ingemar Dierickx and Karel Cool (1989) argued that as a general rule, priced resources could not be expected to contribute to competitive 
advantage, exactly because they are priced. ${ }^{16}$ Although Dierickx and Cool were not entirely forthcoming about the logic of this conclusion, their argument implicitly assumes such a degree of market efficiency and bargaining power on the supply side of factor markets that the supply side can appropriate any surplus that a resource may create when deployed to any firm on the demand side of the market. Although this is clearly an extreme argument, it is one that is echoed in much contemporary strategic management theory. Thus, Lippman and Rumelt (2003a: 1085) argue that "the heart of business management and strategy concerns the creation, evaluation, manipulation, administration, and deployment of unpriced specialized resource combinations." While we agree wholeheartedly with the emphasis on "the creation of ... specialized resource combinations" as the crux of strategy, we fail to see the importance of these combinations being “unpriced.” Perhaps all Lippman and Rumelt mean is that the "resource combination" in question is indeed so specialized that no market exists for it, and that the "synergies” produced by the combination are not "priced away." The existence of such resource combinations is, of course, completely consistent here with the emphasis on entrepreneurial search and judgment in a search space defined by multiple combinations of capital goods.

However, it seems to be of no fundamental significance whether "specialized resource combinations" are priced per se; what matters is how close to the DNPV of the specialized resource combination relevant prices are. We have stressed throughout that entrepreneurs search for resource combinations that are high in appropriable value and that they exercise judgment concerning the choice of such bundles. The search that entrepreneurs perform depend on their prior experience and the theories they hold of the architecture of the landscape they search over. These are highly subjective, as is entrepreneurial judgment itself. Because of the subjective nature of theories, experience, and judgment, agents very likely hold divergent expectations concerning the values of resources. Entrepreneurs that have engaged in search may hold expectations concerning resource values that are superior to those of

\footnotetext{
${ }^{16}$ Partly as a result of this paper, and what appears to be a consensus on this point, much of the attention in strategic management shifted to "complex," "socially distributed" and "knowledge-based" resources, such as “competencies" or "dynamic capabilities” in the 1990s (e.g., Teece, Pisano, and Shuen, 1997), that is, resources that are not (for various transaction-cost related reasons) not traded on factor markets.
} 
the market, which implies that they may beat the market in terms of acquiring resources at a price below the DNPV. This may be sorted under the rubric of “asymmetric information” (Barney, 1986; Rumelt, 1987; Makadok and Barney, 2001); however, the state of asymmetric information existing between the entrepreneur and the market is the outcome of a process of searching and judging.

The importance of judgment and resource complementarity. Even highly specialized resource combinations consist of resources, many of which are in fact priced. Much — and at the limit: all — of the rent of such a combination may be priced away by pricing the resources that make up the combination. However, the entrepreneurial perspective adopted here implies that this is not likely to happen for many specialized resource combinations. Entrepreneurship (as the execerise of judgment) is an unpriced resource (or at least one that is highly costly to trade over markets). In one interpretation, Knight (1921) argued that firms exist because it is usually prohibitively costly to trade judgment; hence, the entrepreneur needs to start his own firm to earn rents from his judgment (Langlois and Cosel, 1993; Foss et al., 2006). However, judgment also holds the key to understanding why not all "synergies” are priced away: First, the particular "specialized resource combination" is a product of the judgment of entrepreneurs. They are likely to have unique insight into the value of this combination and may therefore "beat the market" (as suggested above). Second, the judgment of entrepreneurs is itself a necessary complementary resource. The other resources in the combination derive part of their value from their being in the combination with the entrepreneur's judgment. However, the value of the entrepreneur's judgment cannot easily be assessed, if at all (if it could, judgment would trade in markets). Therefore, the values of complementary resources are also hard to assess. In sum, "synergies” may not be priced away because of complementarities to non-traded entrepreneurial judgment.

\section{CONCLUDING DISCUSSION}

The contribution of this paper has been to explore the implications of explicitly grounding contemporary thinking about strategic management in Austrian notions of heterogeneous capital and entrepreneurship. We began by arguing that strategic management's dominant perspective, the RBV, 
represents a halfway house between mainstream economics and Austrian economics. In spite of features that make it resemble Austrianism, notably the stress on firms as collections of heterogeneous resources and the emphasis on differential expectations, the RBV is strongly wedded to notions of equilibrium, the core RBV model being essentially a patched-up competitive equilibrium model. An implication of this is that it may be fruitful to take the RBV in a more Austrian direction by exploiting some of the existing overlaps. In particular, we argued that Austrian capital theory represents a natural and systematic underpinning for the RBV emphasis on heterogeneous resources. This became even more obvious when we combined this capital theoretic view with Austrian notions of entrepreneurship. In order to get a better grasp of entrepreneurial activity in the context of a structure of heterogeneous capital, we made use of the theory of complex systems, arguing that this approach conveniently frames those search processes that are an integral part of the exercise of entrepreneurship. Thus, in terms of research strategies concerning who Austrian scholars might collaborate with or gain inspiration from, and which new areas they may “colonize,” the present paper suggests that Austrians would do well to take an interest in the theory of complex systems associated with Simon (1962) and those who have built on this paper, and it suggests that Austrian scholars may contribute significantly to the development of strategic management theory (cf. also Lewin and Phelan, 1999, 2000, 2002).

Some may see the dynamic RBV that has been advocated here as essentially Schumpeterian because of the emphasis on "new combinations" of heterogeneous capital goods made in situations where current prices provide little guidance to which future resources may be profitable. However, the approach advocated here differs from Schumpeter's (1934) in at least two ways: Austrian capital theory is an essential part of the dynamic RBV, but equilibrium is not. In contrast, capital theory was not an important part of Schumpeter's framework, while general equilibrium was.

As Barney (2001) and Lippman and Rumelt (2003) indicate, an important future research stream in the RBV will concern incorporating entrepreneurship in this view. We wholeheartedly agree and submit that Austrian insights in capital and entrepreneurship will be of substantial use here. Empirical research may look more closely at entrepreneurial search, assessment and judgment, and how entrepreneurial expectations are formed by experience. 


\section{REFERENCES}

Bain, J.S. 1956. Barriers to New Competition. Cambridge: Harvard University Press.

Barney, Jay B. 1986. “Strategic Factor Markets”, Management Science 32: 1231-1241.

Barney, Jay B. 1991. "Firm Resources and Sustained Competitive Advantage”, Journal of Management 17: 99-120.

Barney, Jay B. 2001 “Is the Resource-Based 'View’ a Useful Perspective for Strategic Management Research? Yes,” Academy of Management Review 26: 41-56.

Barzel, Yoram. 1997. Economic Analysis of Property Rights. Cambridge: Cambridge University Press.

Baumol, William J., Panzar, John C. and Willig, Robert D. 1982. “Contestable Markets: An Uprising in the Theory of Industry Structure: Reply.” The American Economic Review 73 (3).

Brozen, Yale. 1971 'The Persistence of 'High Rates of Return' in High-Stable Concentration Industries,” Journal of Law and Economics 14: 501-512.

Cantillon, Richard. 1755. Essai sur la nature de commerce en géneral. Henry Higgs, ed. London: Macmillan, 1931.

Casson, Mark C. 1982. The Entrepreneur: An Economic Theory. Cheltenham, UK: Edward Elgar.

Casson, Mark C. 1993. “Entrepreneurship,” in David H. Henderson, ed., The Fortune Encyclopedia of Economics. New York: Warner Books.

Chiles, Todd H. 2003. "Process Theorizing: Too Important to Ignore in a Kaleidic World” Academy of Management Learning and Education 2(3): 288-91.

Choi, Young-Back.. 1993. Paradigms and Conventions: Uncertainty, Decision Making and Entrepreneurship. Ann Arbor: University of Michigan Press.

Coase, Ronald H. 1992. “The Institutional Structure of Production,” American Economic Review82: 713-719.

Cowan, Robin and Rizzo, Mario J, 1996. "The Genetic-Causal Tradition and Modern Economic Theory”, Kyklos, Blackwell Publishing 49(3): 273-317.

Debreu, Gerard. 1959. Theory of Value. New York: Wiley.

Demsetz, Harold. 1973. "Industrial Structure, Market Rivalry, and Public Policy”, Journal of Law and Economics 16: 1-10.

Demsetz, Harold. 1974. “Two Systems of Belief About Monopoly”, in idem. 1989. Efficiency, Competition, and Policy. Oxford: Basil Blackwell.

Demsetz, Harold. 1982. "Barriers to Entry”, in idem. 1989. Efficiency, Competition, and Policy. Oxford: Basil Blackwell.

Demsetz, Harold. 1989. “The Indivisibility Rent Theory of Measured Oligopoly Profit”, in idem. 1989. Efficiency, Competition, and Policy. Oxford: Basil Blackwell. 
Denrell, Jerker, Fang, Christina and Winter, Sidney G. 2003. "The Economic of Strategic Opportunity.” Strategic Management Journal, 24: 977-990.

Dierickx, I.and Cool, K. 1989. “Asset Stock Accumulation and the Sustainability of Competitive Advantage”. Management Science 35: 1504-11.

Fleming, L. 2001. "Recombinant Uncertainty in Technological Search”. Management Science 47: 117-132.

Foss, Nicolai J. 1996b. “Harold Malmgren's Analysis of the Firm: Lessons for Modern Theorists?” Review of Political Economy 8: 349-366.

Foss, Nicolai J. 2000. Equilibrium vs Evolution in the Resource-based Perspective in Nicolai J. Foss and Paul L. Robertson, eds. 2000. Resources, Technology, and Strategy. London: Routledge.

Foss, Nicolai J. 2003. “Selective Intervention and Internal Hybrids: Interpreting and Learning from the Rise and

Decline of the Oticon Spaghetti Organization”. Strategic Organization 14(3): 331-349.

Foss, Nicolai J.and Klein, Peter G. 2005. "Entrepreneurship and Economic Theory of the Firm: Any Gains from Trade?,” in Handbook of Entrepreneurship.

Foss, Kirsten, Foss, Nicolai J., Klein, G..P. and Klein, S.K. 2005. "Austrian Capital Theory and the Link Between Entrepreneurship and the Theory of the Firm”. CKG Working Paper, 2005-5.

Gartner, W.B. 1990. “What are We Talking about When We Talk about Entrepreneurship?” Journal of Business Venturing. 5:15-28.

Garrison, Roger W. 2001. Time and Money: The Macroeconomics of Capital Structure. London: Routledge.

Ghemawat, P. 1991. Commitment: The Dynamic of Strategy. New York: The Free Press.

Hamel, G. and Prahalad, C.K. 1994. Competing for the Future. Boston: Harvard Business School Press.

Harper, David. 1995. Entrepreneurship and the Market Process. London: Routledge.

Hayek, Friedrich A. von. 1928. ”Das intertemporale Gleichgewichtssystem der Preise und die

Bewegungen des “Geldwertes””. Weltwirtschaftliches Archiv 28: 33-76.

Hayek, Friedrich A. von. 1941. The Pure Theory of Capital, London.

Hayek, Friedrich A. von. 1945. “The Use of the Knowledge in Society.” The American Economic Review.55: 519-530.

Hayek, Friedrich A. von .1946. The Meaning of Competition. In: Hayek (1948).

Hayek, Friedrich A. von.1948. Individualism and Economic Order. Chicago: University of Chicago Press. 
Henderson, Rebecca M. and Clark, Kim B. 1990. “Architectural Innovation: The Reconfiguration of Existing Product Technologies and the Failure of Established Firms”. Administrative Science Quarterly, 35.

Hill, Charles W. L. and Deeds, David L. 1996. "The Importance of Industry Structure for the Determination of Firm Profitability: A Neo-Austrian Perspective." Journal of Management Studies 33(4): 429-51.

Jacobson, R. 1992. “The Austrian School of Strategy.” Academy of Management Review 17: 782-807.

Kauffman, S.A. 1993. Origins of Order: Self-Organization and Selection in Evolution.Oxford: Oxford University Press.

Kay, John A. 1990. “Economics and Business,” Economic Journal

Kirzner, Israel M. 1966. An Essay on Capital. New York: Augustus M. Kelley.

Kirzner, Israel M. 1973. Competition and Entrepreneurship. Chicago: University of Chicago Press.

Kizner, Israel M. 1997. "Entrepreneurial Discovery and the Competitive Market Process: An Austrian approach”. Journal of Economic Literature. 35: 60-85.

Knight, Frank H. 1921. Risk, Uncertainty, and Profit. New York: August M. Kelley.

Knott, Anne Marie. 1998. “The Organizational Routines Factor Market Paradox,” Working Paper, The Wharton School.

Kor, Yasemin Y. and Mahoney, Joseph T. 2000. "Penrose’s Resource-Based Approach: The Process and Product of Research Creativity.” Journal of Management Studies 37(1): 109-39.

Lachman, Ludwig M. 1947. “Complementarity and Substitution in the Theory of Capital,” Economica 14: $108-119$.

Lachmann, Ludwig M. 1956. Capital and Its Structure. 1977 re-issue. Kansas City: Sheed Andrews and McNeel.

Lachmann, Ludwig M. 1976. "From Mises to Shackle: An Essay on Austrian Economics and the Kaleidic Society”, Journal of Economic Literature 14(1): 54-62 (March).

Lachmann, Ludwig M. 1977. Capital Expectations and the Market Process: Essays in the Theory of the Market Economy. W. E. Grinder ed. Kansas City: Sheed Andrews and McMeel.

Lachmann, Ludwig M. 1986. The Market as an Economic Process. Oxford: Basil Blackwell.

Langlois, Richard N. 2002. “A Modularity Theory of the Firm,” in Nicolai J Foss and Peter G Klein, eds. 2002. Entrepreneurship and the Firm: Austrian Approaches to Economic Organization. Aldershot: Edward Elgar.

Langlois, Richard N. 2003. "The vanishing hand: the changing dynamics of industrial capitalism". Industrial and Corporate Change. Oxford University Press 12(2):351-385.

Langlois, Richard N. and Cosgel, Metin. 1993. “Frank Knight on Risk, Uncertainty, and the Firm: A 
New Interpretation”. Economic Inquiry 31: 456-65.

Leijonhufvud, Axel. 1986. “Capitalism and the Factory System”. In Richard N. Langlois, ed. 1986. Economics as a Process: Essays in the New Institutional Economics. Cambridge: Cambridge University Press.

Levinthal, Daniel. 1997. “Adaptation on Rugged Landscapes,” Management Science 43: 934-950.

Lewin, Peter and Phelan, Steven. 1999. “Firms, Strategies, and Resources”. Quarterly Journal of Austrian Economics 2(2): 1-18.

Lewin, Peter and Phelan, Steven. 2000. “An Austrian Theory of the Firm”. Review of Austrian Economics 13: 59-79.

Lewin, Peter and Phelan, Steven. 2002. "Rents and resources: a market process perspective.” In Nicolai J. Foss and G.P. Klein (ed.) (2002). Entrepreneurship and the Firm: Austrian Perspective on Economic Organization. Aldershot: Edward Elgar.

Lewin, Peter. 1999. Capital in Disequilibrium: The Role of Capital in a Changing World. New York and London: Routledge.

Lewin, Peter. 2005. “The Firm in Disequilibrium: Contributions from the Austrian Tradition.” Working Paper of School of Management University of Texas at Dallas.

Lippman, Steven A. and Rumelt, Richard P. 1982. "Uncertain imitability: an analysis of inter firm deficiency under competition”. The Bell Journal of Economics 13: 418-438.

Lippman, Steven A. and Rumelt, Richard P. 2003a."The Payments Perspective”. Strategic Management Journal. 24: 903-927.

Lippman, Steven A. and Rumelt, Richard P. 2003b. "The Bargaining Perspective”. Strategic Management Journal. 24: 1069-86

Loasby, Brian J. 1976. Choice, Complexity, and Ignorance. Cambridge: Cambridge University Press.

Lumpkin, G.T. and Dess, G.G. 1996. "Clarifying the Entrepreneurial Orientation Construct and Linking it to Performance”. Academy of Management Review 21: 135-72.

Machovec, Frank M. 1995. Perfect Competition and the Transformation of Economics. London: Routledge.

Makadok, Richard and Barney, Jay B. 2001. "Strategic Factor Market Intelligence: an Application of Information Economics to Strategy Formulation and Competitor Intelligence”. Management Science 47: 1621-1638.

Makowski, Louis and Ostroy, Joseph M.. 2001. 'Perfect Competition and the Creativity of Markets," Journal of Economic Literature 39: 479-435.

Matthews, John. 2006. Strategizing, Disequilibrium, and Profit. Stanford: Stanford University Pres.

Menger, Carl.. 1871. Principles of Economics. New York: New York University Press, 1985. 
Montgomery, C.A.. and Wemerfelt, B. 1988. “Diversification, Ricardian Rents, and Tobin’s Q”. Rand Journal of Economics 19(4): 623-632.

Mises, Ludwig von. 1949. Human Action. New Haven: Yale University Press.

Nelson, R. and Winter, S. 1982. An Evolutionar Ttheory of Economic Change. Cambridge, MA: The Belknap press.

Nickerson, Jackson and Zenger, Todd. 2004. “A Knowledge-based Theory of the Firm: The Problem-Solving Perspective”. Organization Science 15(6): 617-632

Peltzman, Sam. 1977. “The Gains and Losses from Industrial Concentration”. Journal of Law and Economics 20: 229-263.

Penrose, Edith T. 1959. The Theory of the Growth of the Firm. Oxford: Oxford University Press.

Peteraf, Margaret A. 1993. “The Cornerstones of Competitive Advantage: A Resource-Based View”. Strategic Management Journal 14: 179-191.

Porter, Michael E. 1980. Competitive Strategy. New York: The Free Press.

Porter, Michael E .1981. “The Contribution of Industrial Organization to Strategic Management”. Academy of Management Review 6(4).

Porter, Michael E. 1985. Competitive Advantage: Creating and Sustaining Superior Performance. New York: the Free Press.

Priem, R.L.. and Butler, J. E. 2001a. "Is the Resource Based "View" a Useful Perspective for Strategic Management Research?” Academy of Management Review 26(1): 22-40.

Reder, Melvin W. 1982. “Chicago Economics: Permanence and change”. Journal of Economic Literature. Vol. XX.

Rivkin, Jan. 2000. “Imitation of Complex Strategies”. Management Science 46: 824-844.

Roberts, Peter W. and Eisenhardt, K.M. 2003. “Austrian Insights on Strategic Organization: From Market Insights to Implications for Firms”. Strategic Organization 1: 345-52.

Rumelt, Richard P. 1984. “Towards a Strategic Theory of the Firm,” in Richard B. Lamb, ed. Competitive Strategic Management. New Jersey: Englewood Cliffs.

Rumelt, Richard. P. 1987. “Theory, Strategy, and Entrepreneurship,” in D. J. Teece (ed.). The Competitive challenge: Strategies for industrial innovation and renewal. 137-158. Cambridge, MA: Ballinger.

Salerno, Joseph. 1999. “The Place of Mises’s Human Action in the Development of Modern Economic Thought”. Quarterly Journal of Austrian Economics 2: 35-65.

Schaefer, Scott. 1999. "Product Design Partitions with Complementary Components”. Journal of Economic Behavior and Organization 38: 311-330.

Scherer, F.M. 1980. Industrial Market Structure and Economic Performance. Boston: Houghton Mifflin. 
Schumpeter, Joseph A. 1911. The Theory of Economic Development: An Inquiry into Profits, Capital, Credit, Interest, and the Business Cycle. Translated by Redvers Opie. Cambridge, Mass.:Harvard University Press, 1934.

Shane, Scott. 2000. "Prior Knowledge and the Discovery of Entrepreneurial Opportunities". Organization Science 11 (4): 448-469.

Shane, Scott 2003. A General Theory of Entrepreneurship: The Individual-Opportunity Nexus. Aldershot, UK: Edward Elgar.

Simon, Herbert A. 1955. “A Behavioral Model of Rational Choice”. Quarterly Jounal of Economics 69: 99-118.

Simon, Herbert A. 1962. "The Architecture of Complexity". Proceedings of the American Philosophical Society 156: 467-482.

Solow, Robert. 1957. "Technical Change and the Aggregate Production Function”. Review of Economics and Statistics 39: 312-20.

Teece, David J., Pisano, Gary and Shuen, Amy 1997. "Dynamic Capabilities and Strategic Management”. Strategic Management Journal 18(7): 509-533.

Tirole, Jean. 1988. The Theory of Industrial Organization. Cambridge, MA: MIT Press.

Vaughn, Karen I. 1994. Austrian Economics in America:The Migration of a Tradition. Cambridge: Cambridge University Press.

Wernerfelt, Birger. 1984. “A Resource-based View of the Firm”. Strategic Management Journal 5: 171-180.

Westgren, Randall E. 1995. "Firm Resources, Industrial Organization, and Austrian Economics: The Bases for a New Strategic Management Approach to Competitiveness”. In G.H. Peters and Douglas D. Hedley, eds. Agricultural Competitiveness: Market Forces and Policy Choice: Proceedings of the Twenty-Second International Conference of Agricultural Economists. Aldershot, U.K.: Dartmouth.

Witt, Ulrich. 1998a. "Imagination and Leadership: the Neglected Dimension of an Evolutionary Theory of the Firm”. Journal of Economic Behavior and Organization 35: 161-77.

Witt, Ulrich. 1998b. “Do Entrepreneurs Need Firms?” Review of Austrian Economics 11: 99-109. Young, Allyn. 1928. “Increasing Returns and Economic Progress”. The Economic Journal 38: 527-42. 


\section{SMG - Working Papers \\ www.cbs.dk/smg \\ 2003}

2003-1: Nicolai J. Foss, Kenneth Husted, Snejina Michailova, and Torben Pedersen: Governing Knowledge Processes: Theoretical Foundations and Research Opportunities.

2003-2: Yves Doz, Nicolai J. Foss, Stefanie Lenway, Marjorie Lyles, Silvia Massini, Thomas P. Murtha and Torben Pedersen: Future Frontiers in International Management Research: Innovation, Knowledge Creation, and Change in Multinational Companies.

2003-3: Snejina Michailova and Kate Hutchings: The Impact of In-Groups and OutGroups on Knowledge Sharing in Russia and China CKG Working Paper.

2003-4: Nicolai J. Foss and Torben Pedersen : The MNC as a Knowledge Structure: The Roles of Knowledge Sources and Organizational Instruments in MNC Knowledge Management CKG Working Paper.

2003-5: Kirsten Foss, Nicolai J. Foss and Xosé H. Vázquez-Vicente: “Tying the Manager's Hands": How Firms Can Make Credible Commitments That Make Opportunistic Managerial Intervention Less Likely CKG Working Paper.

2003-6: Marjorie Lyles, Torben Pedersen and Bent Petersen: Knowledge Gaps: The Case of Knowledge about Foreign Entry.

2003-7: Kirsten Foss and Nicolai J. Foss: The Limits to Designed Orders: Authority under "Distributed Knowledge" CKG Working Paper.

2003-8: Jens Gammelgaard and Torben Pedersen: Internal versus External Knowledge Sourcing of Subsidiaries - An Organizational Trade-Off.

2003-9: Kate Hutchings and Snejina Michailova: Facilitating Knowledge Sharing in Russian and Chinese Subsidiaries: The Importance of Groups and Personal Networks Accepted for publication in Journal of Knowledge Management.

2003-10: Volker Mahnke, Torben Pedersen and Markus Verzin: The impact of knowledge management on MNC subsidiary performance: the role of absorptive capacity CKG Working Paper.

2003-11: Tomas Hellström and Kenneth Husted: Mapping Knowledge and Intellectual Capital in Academic Environments: A Focus Group Study Accepted for publication in Journal of Intellectual Capital CKG Working Paper.

2003-12: Nicolai J Foss: Cognition and Motivation in the Theory of the Firm: Interaction or "Never the Twain Shall Meet"? Accepted for publication in Journal des Economistes et des Etudes Humaines CKG Working Paper.

2003-13: Dana Minbaeva and Snejina Michailova: Knowledge transfer and expatriation practices in MNCs: The role of disseminative capacity.

2003-14: Christian Vintergaard and Kenneth Husted: Enhancing selective capacity through venture bases. 


\section{4}

2004-1: Nicolai J. Foss: Knowledge and Organization in the Theory of the Multinational Corporation: Some Foundational Issues

2004-2: Dana B. Minbaeva: HRM practices and MNC knowledge transfer

2004-3: Bo Bernhard Nielsen and Snejina Michailova: Toward a phase-model of global knowledge management systems in multinational corporations

2004-4: Kirsten Foss \& Nicolai J Foss: The Next Step in the Evolution of the RBV: Integration with Transaction Cost Economics

2004-5: Teppo Felin \& Nicolai J. Foss: Methodological Individualism and the Organizational Capabilities Approach

2004-6: Jens Gammelgaard, Kenneth Husted, Snejina Michailova: Knowledge-sharing Behavior and Post-acquisition Integration Failure

2004-7: Jens Gammelgaard: Multinational Exploration of Acquired R\&D Activities

2004-8: Christoph Dörrenbächer \& Jens Gammelgaard: Subsidiary Upgrading? Strategic Inertia in the Development of German-owned Subsidiaries in Hungary

2004-9: Kirsten Foss \& Nicolai J. Foss: Resources and Transaction Costs: How the Economics of Property Rights Furthers the Resource-based View

2004-10: Jens Gammelgaard \& Thomas Ritter: The Knowledge Retrieval Matrix: Codification and Personification as Separate Strategies

2004-11: Nicolai J. Foss \& Peter G. Klein: Entrepreneurship and the Economic Theory of the Firm: Any Gains from Trade?

2004-12: Akshey Gupta \& Snejina Michailova: Knowledge Sharing in Knowledge-Intensive Firms: Opportunities and Limitations of Knowledge Codification

2004-13: Snejina Michailova \& Kate Hutchings: Knowledge Sharing and National Culture: A Comparison Between China and Russia

\section{5}

2005-1: Keld Laursen \& Ammon Salter: My Precious - The Role of Appropriability Strategies in Shaping Innovative Performance

2005-2: Nicolai J. Foss \& Peter G. Klein: The Theory of the Firm and Its Critics: A Stocktaking and Assessment

2005-3: Lars Bo Jeppesen \& Lars Frederiksen: Why Firm-Established User Communities Work for Innovation: The Personal Attributes of Innovative Users in the Case of Computer-Controlled Music

2005-4: Dana B. Minbaeva: Negative Impact of Hrm Complementarity on Knowledge Transfer in Mncs

2005-5: Kirsten Foss, Nicolai J. Foss, Peter G. Klein \& Sandra K. Klein: Austrian Capital Theory and the Link Between Entrepreneurship and the Theory of the Firm 
2005-1: Nicolai J. Foss: The Knowledge Governance Approach

2005-2: Torben J. Andersen: Capital Structure, Environmental Dynamism, Innovation Strategy, and Strategic Risk Management

2005-3: Torben J. Andersen: A Strategic Risk Management Framework for Multinational Enterprise

2005-4: Peter Holdt Christensen: Facilitating Knowledge Sharing: A Conceptual Framework

2005-5 Kirsten Foss \& Nicolai J. Foss: Hands Off! How Organizational Design Can Make Delegation Credible

2005-6 Marjorie A. Lyles, Torben Pedersen \& Bent Petersen: Closing the Knowledge Gap in Foreign Markets - A Learning Perspective

2005-7 Christian Geisler Asmussen, Torben Pedersen \& Bent Petersen: How do we capture "Global Specialization" when measuring firms' degree of internationalization?

2005-8 Kirsten Foss \& Nicolai J. Foss: Simon on Problem-Solving: Implications for New Organizational Forms

2005-9 Birgitte Grøgaard, Carmine Gioia \& Gabriel R.G. Benito: An Empirical Investigation of the Role of Industry Factors in the Internationalization Patterns of Firms

2005-10 Torben J. Andersen: The Performance and Risk Management Implications of Multinationality: An Industry Perspective

2005-11 Nicolai J. Foss: The Scientific Progress in Strategic Management: The case of the Resource-based view

2005-12 Koen H. Heimeriks: Alliance capability as a mediator between experience and alliance performance: An empirical investigation into the alliance capability development process

2005-13 Koen H. Heimeriks, Geert Duysters \& Wim Vanhaverbeke: Developing Alliance Capabilities: An Empirical Study

2005-14 JC Spender: Management, Rational or Creative? A Knowledge-Based Discussion

\section{6}

2006-1: Nicolai J. Foss \& Peter G. Klein: The Emergence of the Modern Theory of the Firm

2006-2: Teppo Felin \& Nicolai J. Foss: Individuals and Organizations: Thoughts on a Micro-Foundations Project for Strategic Management and Organizational Analysis

2006-3: Volker Mahnke, Torben Pedersen \& Markus Venzin: Does Knowledge Sharing Pay? An MNC Subsidiary Perspective on Knowledge Outflows

2006-4: Torben Pedersen: Determining Factors of Subsidiary Development 
2006-5 Ibuki Ishikawa: The source of competitive advantage and entrepreneurial judgment in the RBV: Insights from the Austrian school perspective

2006-6 Nicolai J. Foss \& Ibuki Ishikawa: Towards a dynamic resource-based view: Insights from Austrian capital and entrepreneurship theory 